\title{
Correction to: Your Fear is My Fear: The Relationship Between Parental and Offspring Anxieties
}

\author{
Dirk Adolph $^{1}$ (D) $\cdot$ Jürgen Margraf ${ }^{1} \cdot$ Silvia Schneider $^{1}$
}

Published online: 25 June 2021

(c) The Author(s) 2021

\section{Correction to: Child Psychiatry \& Human Development https://doi.org/10.1007/s10578-020-01060-y}

The article "Your Fear is My Fear: The Relationship Between Parental and Ofspring Anxieties", written by Dirk Adolph, Jürgen Margraf, Silvia Schneider, was originally published electronically on the publisher's internet portal (https://link.springer.com/article/10.1007/s10578020-01031-3) on 18 September 2020 without open access. With the author(s)' decision to opt for Open Choice, the copyright of the article changed on 8 June 2021 to $($ ) The Author(s) 2021 and the article is forthwith distributed under the terms of the Creative Commons Attribution 4.0 International License (http://creativecommons.org/licenses/by/4. 0/), which permits use, duplication, adaptation, distribution and reproduction in any medium or format, as long as you give appropriate credit to the original author(s) and the source, provide a link to the Creative Commons license and indicate if changes were made.
The Open Access funding enabled and organized by Projekt DEAL.

The original article has been corrected.

Open Access This article is licensed under a Creative Commons Attribution 4.0 International License, which permits use, sharing, adaptation, distribution and reproduction in any medium or format, as long as you give appropriate credit to the original author(s) and the source, provide a link to the Creative Commons licence, and indicate if changes were made. The images or other third party material in this article are included in the article's Creative Commons licence, unless indicated otherwise in a credit line to the material. If material is not included in the article's Creative Commons licence and your intended use is not permitted by statutory regulation or exceeds the permitted use, you will need to obtain permission directly from the copyright holder. To view a copy of this licence, visit http://creativecommons.org/licenses/by/4.0/.

Publisher's Note Springer Nature remains neutral with regard to jurisdictional claims in published maps and institutional affiliations.

The original article can be found online at https://doi.org/10.1007/ s10578-020-01060-y.

Dirk Adolph
dirk.adolph@rub.de

1 Mental Health Research and Treatment Center, Ruhr-University Bochum, Massenbergstrasse 9-13, 44847 Bochum, Germany 